\title{
Factors affecting road mortality and the suitability of road verges for butterflies
}

\author{
Piotr Skórka ${ }^{\mathrm{a}, *}$, Magdalena Lenda ${ }^{\mathrm{b}}$, Dawid Moroń ${ }^{\mathrm{c}}$, Konrad Kalarus ${ }^{\mathrm{d}}$, Piotr Tryjanowski ${ }^{\mathrm{a}}$ \\ anstitute of Zoology, Poznan University of Life Sciences, Wojska Polskiego 71 C, 60-625 Poznan, Poland \\ ${ }^{\mathrm{b}}$ Institute of Nature Conservation, Polish Academy of Sciences, Mickiewicza 33, 31-120 Kraków, Poland \\ ${ }^{\mathrm{c}}$ Institute of Systematics and Evolution of Animals, Polish Academy of Sciences, Slawkowska 17, 31-016 Kraków, Poland \\ ${ }^{\mathrm{d}}$ Institute of Environmental Sciences, Jagiellonian University, Gronostajowa 7, 30-387 Kraków, Poland
}

\section{A R T I C L E I N F O}

\section{Article history:}

Received 30 July 2012

Received in revised form 10 December 2012

Accepted 20 December 2012

\section{Keywords:}

Cars

Habitat fragmentation

Insects

Landscape

Mortality

\begin{abstract}
A B S T R A C T
Little is known of the impact of roads on insect mortality. This is a significant gap, because road verges are regarded as an important tool for insect conservation. In this study, we investigated which factors affect the number of roadkills in grassland butterflies and, simultaneously, the species composition and abundance on road verges. We established sixty transects, two hundred metres long, on roads in farmland areas and with differing traffic volume. Each transect consisted of two parallel lines, one on either side of the road. Ordination methods showed that the species composition of the butterflies killed on the roads was primarily explained by the species composition of those living on the road verges. At least $6.8 \%$ of the butterflies were estimated to end up roadkilled. Also, the number of species and abundance of butterflies killed on the roads were positively dependent on both the abundance of butterflies on the road verges and on the traffic volume, but negatively correlated with the richness of plant species on the road verges. However, the proportion of individuals killed was negatively linked with the abundance of butterflies on the road verges, the richness of the plant species and the share of grassland in the landscape. There was a statistically significant tendency for small-bodied species to be overrepresented in the roadkill samples. Our results indicate that the verges which were of high conservation value for butterflies suffered the least from road mortality. The sowing of plant species, less frequent mowing and maintaining a high grassland cover in the vicinity of roads are recommended conservation actions for the improved conservation value of road verges for butterflies.
\end{abstract}

(c) 2012 Elsevier Ltd. All rights reserved.

\section{Introduction}

The development of road networks and increased traffic volume is one the most significant causes of habitat fragmentation (Forman and Alexander, 1998; Trombulak and Frissell, 2000; Forman et al., 2003; Fahrig and Rytwinski, 2009; Selva et al., 2011) that has lead to decreased populations of many animal species (Warren et al., 2001; Fahrig, 2003; Forman et al., 2003; Thomas et al., 2004; Biesmeijer et al., 2006; Silva et al., 2012). Several studies, mostly carried out on mammals, amphibians and some insects, indicate that roads dividing habitat fragments may be an obstacle to the movements of individuals and, therefore, to the gene flow between the fragments (Bhattacharya et al., 2003; Shepard et al., 2008; Smith-Patten and Patten, 2008; Jackson and Fahrig, 2011; Soluk et al., 2011; Neumann et al., 2012). On the other hand, many studies indicate that the negative effects of roads may be mitigated by the high conservation value of road verges (a strip of grass or

\footnotetext{
* Corresponding author. Tel.: +48 888151674.

E-mail address: skorasp@poczta.onet.pl (P. Skórka).
}

other vegetation beside a road) or other habitats associated with roads (Ries et al., 2001; Saarinen et al., 2005; Valtonen et al., 2006, 2007). Road verges may serve as dispersal corridors and be a suitable habitat for many insects (Forman and Alexander, 1998; Trombulak and Frissell, 2000; Wynhoff et al., 2011). They are considered as being especially favorable for both common and endangered butterflies (Munguira and Thomas, 1992; Ries et al., 2001; Saarinen et al., 2005).

However, if the road mortality is high, then the conservation value of the respective road verges would be diminished. Road networks and traffic volumes are increasing across the globe (Forman and Alexander, 1998; Selva et al., 2011) and thus the estimation of road mortality and establishment of which factors affect the number of roadkills is an essential issue as regards the conservation of insects living on road verges and in semi-natural habitats in the vicinity of roads. Surprisingly, there are only a few estimations of the number of roadkills and the factors determining them (Munguira and Thomas, 1992; Ries et al., 2001). On a larger spatial scale, it has been shown that butterflies are one of the most common insect groups being killed on roads (Mckenna et al., 2001; Rao and Girish, 2007). 
One might predict that the number of road kills may be affected by five major factors: (1) traffic volume; (2) the population size of insects living on road verges; (3) the properties of the road and verge; (4) the landscape composition in the vicinity of roads; and (5) species traits. The greater the volume of traffic, the greater the probability of collision with a car and thus the number of roadkills should be higher for roads with a higher traffic value. Insects usually have low or moderate dispersal abilities; hence most roadkills should be individuals living on road verges or in the proximity of roads. The higher the population density, the higher the chance that the individual will try to emigrate (Nowicki and Vrabec, 2011) and cross the road, exposing itself to the possibility of being hit by a vehicle. Obviously, various verge properties may either cause individuals to remain or induce them to cross the road and migrate. One may also predict that wider verges and verges with a larger supply of resources will provide a habitat sufficient to sustain, and thus retain, individuals (Munguira and Thomas, 1992; Saarinen et al., 2005). However, when the habitat area is restricted and the quality of the resources low, this may prompt dispersal and individuals may be willing to cross the road in order to seek another, more suitable site. Many road verges are regularly mown and this kind of activity may force individuals to search for other, more suitable sites (Valtonen et al., 2006), as has been shown for managed grassland patches (Dover et al., 2010). It may thus be expected that, in rarely mown, wide road verges, with a larger number of nectar and host plant species the chance that individuals will try to emigrate and, in consequence, the number of roadkills, should be lower. Landscape structure may also influence the number of roadkills, as well as the number of species and individuals in habitat patches (Munguira and Thomas, 1992; Saarinen et al., 2005; Öckinger and Smith, 2007; Berg et al., 2011; Vergnes et al., 2012). However, it is difficult, a priori, to put forward precise predictions. One may hypothesize that, the larger the cover of seminatural habitats in the vicinity of roads, the higher the influx of individuals should be, increasing population size on road verges and thus, as stated above, escalating the number of roadkills. However, the opposite effect may also be expected. Road verges are supplementary habitats for most insects and thus, when the share of semi-natural habitats in the vicinity of roads is large, then individuals may be willing to emigrate to those patches, leading to a lower population density on road verges and, in effect, to the probability of a lower road mortality.

As a result of evolutionary history and the interaction of a species with its environment and other species, mortality rate is often species-specific. Species, of course, differ between one another; however, this obvious fact has important consequences for our understanding of car-induced mortality. The traits of some species may mean that they are exposed to a higher risk of collision with cars than occurs for other species. In animals like butterflies, body size may be predictor of road mortality, because this trait influences flying speed (Wickman, 1992; Kingsolver and Srygley, 2000) and thus the probability of collision with a vehicle.

However, one of the greatest problems in understanding animal road mortality is the fact that factors which increase mortality may also have a positive impact on abundance and species richness on road verges, which leads to a conservation dilemma. Therefore, in order to understand effects on mortality and evaluate the value of road verges, the ways in which the factors that have an impact on the number of roadkills would affect the abundance and species richness of butterflies at road verges must be tested simultaneously.

To the best of our knowledge, the foregoing hypotheses have not been investigated in a composite study. An understanding of the factors affecting both the number of roadkills and butterfly population sizes on road verges would be essential to both undertaking appropriate mitigation actions steering them toward the alteration of traffic volume, the properties of road verges, and the surrounding landscape, or, indeed, to all of these factors. The aim of this study was therefore to test the aforementioned predictions on grassland butterflies, which frequently inhabit road verges and are considered to be the flagship of insect conservation, with many of them being commonly known to the general public.

\section{Methods}

\subsection{Study area}

We conducted our study in Southern Poland, on roads in an agricultural landscape in the environs of the cities of Kraków, Tarnów and Rzeszów (Fig. 1; Supplementary material). This is a landscape dominated by cereal crops, which cover $40 \%$ of the study area; root crops, primarily potatoes, cabbage and beet, cover $14 \%$; grasslands cover $10 \%$; fallow covers $10 \%$; forests cover $14 \%$; and human settlements cover $10 \%$. Other habitats cover $2 \%$ of the study area. The average density of the human population is 140 people $\times \mathrm{km}^{-2}$. The climate of the studied area is transitional from oceanic to continental (Wiszniewski, 1973) mean yearly temperature is $8.2{ }^{\circ} \mathrm{C}$ (in July: $18.5^{\circ} \mathrm{C}$, in January: $-3.0^{\circ} \mathrm{C}$ ), annual rain-fall is $645 \mathrm{~mm}$ and mean snow cover thickness is $8 \mathrm{~cm}$ (Lorenc, 2005). The snow cover lies on average from the third week of December to the middle of March (Lorenc, 2005).

\subsection{Selection of transects}

The butterflies killed by cars were collected on 60 transects, each of them $200 \mathrm{~m}$ long. They were selected from a larger sample of randomly chosen sites; however, it was necessary that they met certain criteria. Each transect consisted of two parallel lines, one on either side of the road. Thus the sampling unit used in our analyses were data from these two lines on either side of the road. The

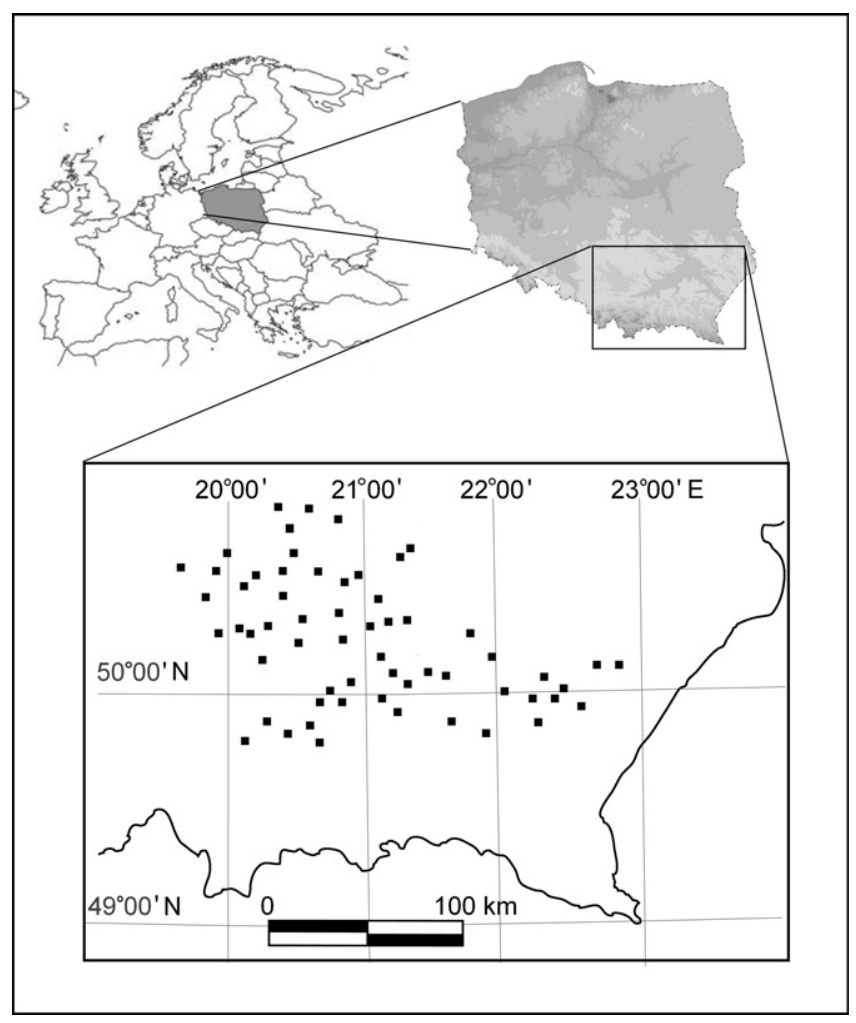

Fig. 1. Map of Poland and location of the region where the roadkills and butterflies on road verges were studied. Black dots indicate the location of transects in this study. 
verges on both sides of the road had to be similar in respect of width and vegetation structure; for example, we omitted sites were one road verge was covered with grass and the other by shrubs or trees (see Supplementary material). The minimal distance between the transects was $2 \mathrm{~km}$. An observer collected the dead butterflies and placed them in $75 \%$ ethanol for identification and use in a different study. Butterflies were collected from the asphalt and about $1 \mathrm{~m}$ wide part of verge adjacent to the road. Immediately after collecting dead butterflies, the observer counted those living on the road verges within a $2.5 \mathrm{~m}$ distance from the road's edge, again, on both sides of the road. We counted the living butterflies after collecting the dead ones in order to not influence the number roadkills collected during the observer's work; we had to capture some individuals to identify them. While collecting both dead and living butterflies, the observer walked at a speed of approximately $100 \mathrm{~m}$ per $10 \mathrm{~min}$. We made twelve surveys in each transect between the beginning of April and the end of September 2010. Butterflies were counted usually every second week, however this time interval varied depending on weather and to cover the peak of adult flight (Vessby et al., 2002; Heliölä and Kuussaari, 2005). Butterflies were surveyed between 9:00 and 16:00 (Central European Time Zone UTC/GMT $+1 \mathrm{~h}$ ) during favorable weather conditions, with temperatures of at least $16^{\circ} \mathrm{C}$, a wind of 3 or less on the Beaufort scale $\left(<4 \mathrm{~m} \times \mathrm{s}^{-1}\right)$, and a cloud cover not exceeding $25 \%$.

\subsection{Variables measured at transects}

The following environmental variables potentially affecting number of roadkills and butterflies at road verges were determined in each transect: (1) traffic volume, (2) the width of the road, (3) the width of the road verge (4) plant species richness on the road verges, (5) the index of mowing frequency, the cover of (6) grassland, (7) forest and (8) human settlements in a $1 \mathrm{~km}$ radius around the transect (see Supplementary material). We also measured flower abundance (as per Skórka et al., 2007); however, this variable was so strongly correlated with plant species richness $(r=0.894, P<0.001)$ that we only used the latter in analyses. To measure traffic volume, we made ten, one-hour-long counts of all the passing vehicles. The vehicle counts were made between 10:00 and 17:00. Times were selected randomly from the time interval 10:00 and 17:00. Counts were done approximately every 2 weeks in each transect with dates as close to butterfly surveys as possible. We also validated our estimates with independent estimates of road traffic published in a report of Administration of Regional Roads in Malopolska Voivodoship (Anonymous, 2007) published on-line (http://www.wrotamalopolski.pl/NR/rdonlyres/ 1EA65A73-82E2-44FD-BCE5-99D45DC194DD/339120/773zal.pdf). In this report estimates of traffic volume are given for several roads in southern Poland. There were 16 roads in this report for which we also had our butterfly transects. There was strong positive correlation $(r=0.891, P<0.001)$ between estimates of traffic made by us and estimates published in the report (Anonymous, 2007). The width of the roads and their verges was either measured with a tape measure or obtained from the road administrator. To estimate the richness of plant species we selected ten square plots of $1 \mathrm{~m}^{2}$, five on each side of the road at random in each transect. Within these plots, we counted all the plant species and measured their cover using the following scale: 1 : $<1 \%, 2$ : $1-10 \%, 3$ : $11-20 \%, \ldots, 11: 91-100 \%$. The plant species were counted twice during the season, in May and in mid-July. The plant species richness used in the analyses is the sum of those recorded within a transect during the two counts. Mowing frequency was noted during each transect survey and we used the index proposed by Valtonen et al. (2006), which describes the total effect of mowing on the vegetation over the study period. The advantage of this index is that it allows researchers to cope with the frequently occurring situation of partially mown verges (Valtonen et al., 2006, see Supplementary material). It may be also treated as a continuous variable, which is advantageous in some analyses. Each survey was given a mowing intensity value $(0=$ no mowing, $1 / 2=$ partial mowing, $1=$ total mowing) and the value was reduced to the lower level, namely from 1 to $1 / 2$ and from $1 / 2$ to 0,7 weeks after mowing, because the vegetation regenerated. We then summed up the values from each survey for a given transect and used the result for our analyses. As per Valtonen et al. (2006), the index for the unmown and partially mown verges was generally the lowest, that of the verges mown in the late summer was intermediate, and that of those mown during the mid-summer period was the highest. Variables 6-8 were read from aerial photos (available from: http:// www.geoportal.gov.pl) digitalized in Quantum GIS 1.7 software and supported by GPS mapping in field.

\subsection{Data handling and statistical analysis}

We related environmental factors to the number of roadkilled species, the number of roadkills in terms of individuals, the proportion of roadkilled species, the proportion of roadkilled individuals, the number of live species and their abundance on the road verges. The proportion of roadkilled species was the number of roadkilled species divided by all the species noted in the transects during all the surveys. Similarly, the proportion of roadkilled individuals refers to the number of all roadkills in a given transect divided by the total number of butterflies noted during transect walks. To identify the factors affecting the number of roadkilled species and the abundance of roadkills, we built general linear models with environmental variables (Table 1) and the number of species and abundance of butterflies living on road verges as explanatory variables, respectively. A similar model was built for the proportion of roadkilled species and proportion of roadkilled individuals. We used proportions because similar factors affected the number of species and abundance by group of roadkills and butterflies living on the road verges; this analysis thus helped us make a clear separation between the environmental factors influencing the number of roadkills and those positively affecting butterfly species richness and abundance on the road verges. In this analysis, we included the total species richness and the abundance of butterflies, dead and alive, as well as the species richness and abundance of butterflies living on the road verges in order to account for the effect of the sample size, since in some transects, the number of butterflies was low, while, in others it was large and this could have affected the estimation of proportions.

We used model selection procedures based on information theory (Burnham and Anderson, 2002). The Akaike information criterion, corrected for the small sample size (AICc), was used to identify the most parsimonious models from set of all possible models. Finally, we ranked all the models built according to their $\triangle \mathrm{AICC}$ (the difference between the given model and the most parsimonious one) values and used those with the lowest AICc, together with associated weight values, the probability that a given model is the best, as the best describing the data. We considered models with a $\triangle$ AICc of lower than two as equally good (Burnham and Anderson, 2002). We used model averaging for estimates of the function slopes of the parameters of interest (Burnham and Anderson, 2002). Finally, the model weights were used to define the relative importance of each explanatory variable across the full set of models evaluated by summing up the weight values of all the models including the explanatory variable of interest (Burnham and Anderson, 2002).

When necessary, we used logarithmic or arc-sin transformation in order to reduce the effects of outlier observations, and for proportions, respectively (Quinn and Keough, 2002). We also checked 
Table 1

Basic statistics of the variables investigated for the roads.

\begin{tabular}{|c|c|c|c|c|}
\hline Variable & Code & Mean \pm SE & Min & Max \\
\hline Number of roadkilled species & - & $5.8 \pm 0.4$ & 0 & 14 \\
\hline Number of roadkilled individuals & - & $9.4 \pm 0.7$ & 0 & 25 \\
\hline Number of species on the road verges & Species & $17.4 \pm 0.8$ & 1 & 28 \\
\hline Abundance on the road verges & Abund & $124.2 \pm 9.2$ & 2 & 352 \\
\hline Proportion of species killed on roads & - & $33.7 \pm 0.9$ & 0 & 100 \\
\hline Proportion of individuals killed on roads & - & $8.2 \pm 2.2$ & 0 & 40 \\
\hline Traffic volume (mean number of cars per hour) & Traffic & $155.4 \pm 12.8$ & 23.2 & 401.5 \\
\hline Mean verge width (m) & VergeW & $3.5 \pm 0.2$ & 1.1 & 6.7 \\
\hline Road width (m) & RoadW & $6.4 \pm 0.1$ & 5.6 & 7.2 \\
\hline Number of plant species on the verges & Plant & $19.9 \pm 0.6$ & 12 & 31 \\
\hline Index of mowing impact & Mown & $2.7 \pm 0.2$ & 0 & 8 \\
\hline Cover of human settlements in a $1-\mathrm{km}$ radius (\%) & Built & $5.2 \pm 0.4$ & 1 & 15 \\
\hline Forest cover in a $1-\mathrm{km}$ radius $(\%)$ & ForCov & $7.9 \pm 1.0$ & 0 & 25 \\
\hline Grassland cover in a $1-\mathrm{km}$ radius (\%) & Grass & $9.8 \pm 0.7$ & 0 & 21 \\
\hline
\end{tabular}

for spatial autocorrelation in the response variables, but found none of significance. In all the regression models, the variables were standardized to allow a direct comparison of the function slopes (betas). Model selection and averaging were run in SAM 4.0 statistical software (Rangel et al., 2010).

A redundancy analysis (RDA) using the CANOCO 4.5 package (Braak and Šmilauer, 2002) was employed in order to relate the abundance of the individual species found killed on road to the environmental variables. The RDA was also used to discover whether the species composition of the butterflies killed by cars was related to the abundance of species living on the road verges. In this analysis the abundance of the butterfly species living on the road verges were treated as environmental variables in CANOCO terminology (Braak and Šmilauer, 2002). At the next stage, we wanted to discover whether environmental variables or the abundances of butterfly species living on road verges would be a more effective predictor of the abundance and species composition of butterflies killed on roads. We carried out a partial RDA with the environmental variables and included the abundance of the species living on the road verges as covariates in order to rule out their effect. Then we performed a partial RDA with the abundances of species living on road verges as "environmental variables" and the real environmental variables as covariates.

To estimate the effects of species traits on road mortality, we related the body size index, namely wing span, and the mobility index to the difference between the expected percentage share of a given species in a group of dead butterflies and the observed percentage share of a species in that group. The expected percentage share of a species was calculated on the basis of its share in the community of live butterflies on the road verges. The negative values of the difference indicate that a given species was rarer in a group of dead butterflies, while the positive values indicate that it is more highly overrepresented in this group than was expected from their share in the community of live butterflies. We used a general linear mixed model to relate species traits and the differences between the expected and real percentage share of the species in a group of dead butterflies. The abundance of butterflies living on road verges was included as a covariate. Butterfly family was assigned as a random effect in order to account for phylogeny. We used model selection and averaging, as described above, to find the best models. The body size index was taken from Sielezniew and Dziekanska (2010) and the mobility index, a 1-9 scale, where 1 means a sedentary species and 9 a very mobile one, was taken from Settele et al. (2000). To compare the expected and real frequencies, we used the $\chi^{2}$ test. If road mortality was a random process, then the expected values should be similar to the real ones. There should also be a strong correlation between the number of butterflies on the road verges and the number of dead ones found on the roads.
We considered that the slopes of the regression function (betas) to be significant if their 95\% confidence intervals (95\% CI) did not overlap with zero. All the statistical parameters, namely betas and means, are quoted with $\mathrm{a} \pm$ standard error (SE).

\section{Results}

We noted 561 roadkilled butterflies of 34 species and 7714 individuals of 42 species on the road verges (Table 2 ). Thus, $6.8 \%$ of the butterflies recorded were dead on the road. The mean percentage of roadkilled individuals for a particular species was $8.2 \%$ and varied from $0 \%$ to $40 \%$; however, the high value was noted in the species which were the least abundant on the road verges. The mean number of roadkilled species per transect, mean abundance of roadkills, mean proportion of roadkilled species per transect, proportion of roadkilled individuals per transect, and mean number of species and individuals living on the road verges are given in Table 1 . Almost all the roadkills were a subsample of the butterfly community on the road verges. There were only two transects where we found one roadkilled Pieris brassicae and Coenonympha pamphilus, neither of which were observed on the road verges there. Both species were found on transects where the species richness and abundance of butterflies by the road were very low, at numbering less than ten individuals during all the counts.

\subsection{Factors affecting the number and proportions of species and individuals killed on roads}

Model selection identified eight equally good models describing the number of roadkilled species (see Supplementary material). All the best models explained 59\% of variation, on average (Supplementary material). The number of roadkilled species was positively related to the number of butterfly species living on the road verges, the index of mowing, the grassland cover in a $1-\mathrm{km}$, the forest cover in a 1-km radius and the traffic volume (Table 3 ). All the models without butterfly species richness on road verges as an explanatory variable had little support $(\Delta \mathrm{AICC}>24)$.

Model selection identified fourteen equally good models describing the abundance of roadkilled butterflies (see Supplementary material). These models explained $58 \%$ of variation, on average (Supplementary material). The number of roadkills was positively related to the abundance of butterflies on the road verges, the traffic volume, the grassland cover in a 1-km radius, the mowing frequency index and the road width (Table 3). The abundance of roadkills was negatively affected by the plant species richness on the road verges and by verge width (Table 3 ). All the models without abundance of butterflies at road verges as an explanatory variable had little support $(\Delta \mathrm{AICC}>20)$. 
Table 2

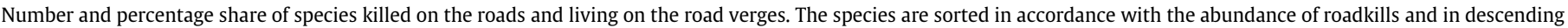

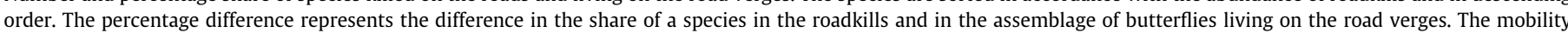
index was adopted from Settele et al. (2000) and the body size index (wingspan) from Sielezniew and Dziekanska (2010).

\begin{tabular}{|c|c|c|c|c|c|c|c|c|}
\hline No. & Species & Roadkills & $\%$ & Abundance at road verges & $\%$ & Difference\% & Mobility & Wingspan (mm) \\
\hline 1 & Coenonympha pamphilus & 90 & 16.0 & 1138 & 14.8 & 1.3 & 3 & 32.0 \\
\hline 2 & Polyommatus icarus & 58 & 10.3 & 616 & 8.0 & 2.4 & 4 & 30.0 \\
\hline 3 & Pieris napi & 38 & 6.8 & 356 & 4.6 & 2.2 & 5 & 42.5 \\
\hline 4 & Pieris rapae & 35 & 6.2 & 836 & 10.8 & -4.6 & 6 & 43.0 \\
\hline 5 & Aphantopus hyperanthus & 32 & 5.7 & 470 & 6.1 & -0.4 & 3 & 40.0 \\
\hline 6 & Lycaena phlaeas & 30 & 5.3 & 103 & 1.3 & 4.0 & 4 & 27.5 \\
\hline 7 & Boloria dia & 28 & 5.0 & 121 & 1.6 & 3.4 & 5 & 34.0 \\
\hline 8 & Thymelicus lineola & 25 & 4.5 & 214 & 2.8 & 1.7 & 4 & 27.0 \\
\hline 9 & Araschnia levana & 22 & 3.9 & 153 & 2.0 & 1.9 & 5 & 31.0 \\
\hline 10 & Erynnis tages & 22 & 3.9 & 174 & 2.3 & 1.7 & 5 & 26.5 \\
\hline 11 & Coenonympha glycerion & 20 & 3.6 & 49 & 0.6 & 2.9 & 2 & 34.0 \\
\hline 12 & Lycaena tityrus & 19 & 3.4 & 89 & 1.2 & 2.2 & 3 & 28.5 \\
\hline 13 & Thymelicus sylvestris & 19 & 3.4 & 166 & 2.2 & 1.2 & 3 & 29.0 \\
\hline 14 & Phengaris nausithous & 15 & 2.7 & 68 & 0.9 & 1.8 & 1 & 34.0 \\
\hline 15 & Callophrys rubi & 14 & 2.5 & 57 & 0.7 & 1.8 & 4 & 24.5 \\
\hline 16 & Leptidea reali & 13 & 2.3 & 48 & 0.6 & 1.7 & 4 & 37.5 \\
\hline 17 & Pyrgus malvae & 12 & 2.1 & 120 & 1.6 & 0.6 & 3 & 25.0 \\
\hline 18 & Anthocharis cardamines & 10 & 1.8 & 357 & 4.6 & -2.8 & 4 & 37.5 \\
\hline 19 & Maniola jurtina & 10 & 1.8 & 321 & 4.2 & -2.4 & 4 & 46.0 \\
\hline 20 & Aglais urticae & 7 & 1.2 & 273 & 3.5 & -2.3 & 6 & 49.0 \\
\hline 21 & Lassiomata megera & 7 & 1.2 & 115 & 1.5 & -0.2 & 4 & 41.0 \\
\hline 22 & Inachis io & 5 & 0.9 & 193 & 2.5 & -1.6 & 6 & 60.0 \\
\hline 23 & Phengaris teleius & 5 & 0.9 & 57 & 0.7 & 0.2 & 2 & 35.5 \\
\hline 24 & Pieris brassicae & 4 & 0.7 & 294 & 3.8 & -3.1 & 7 & 55.0 \\
\hline 25 & Brenthis ino & 3 & 0.5 & 57 & 0.7 & -0.2 & 2 & 40.0 \\
\hline 26 & Gonepteryx rhamni & 3 & 0.5 & 269 & 3.5 & -3.0 & 6 & 51.5 \\
\hline 27 & Issoria lathonia & 3 & 0.5 & 159 & 2.1 & -1.5 & 5 & 44.0 \\
\hline 28 & Melanargia galathea & 3 & 0.5 & 140 & 1.8 & -1.3 & 3 & 47.0 \\
\hline 29 & Ochlodes sylvanus & 3 & 0.5 & 55 & 0.7 & -0.2 & 4 & 30.0 \\
\hline 30 & Plebejus argyrognomon & 2 & 0.4 & 3 & 0.0 & 0.3 & 4 & 28.5 \\
\hline 31 & Argynnis aglaja & 1 & 0.2 & 4 & 0.1 & 0.1 & 3 & 50.0 \\
\hline 32 & Melitea athalia & 1 & 0.2 & 17 & 0.2 & 0.0 & 3 & 38.0 \\
\hline 33 & Papilio machaon & 1 & 0.2 & 206 & 2.7 & -2.5 & 5 & 72.5 \\
\hline 34 & Vanessa atalanta & 1 & 0.2 & 152 & 2.0 & -1.8 & 9 & 61.0 \\
\hline 35 & Argynnis paphia & 0 & 0.0 & 19 & 0.2 & -0.2 & 4 & 60.5 \\
\hline 36 & Celastrina argiolus & 0 & 0.0 & 18 & 0.2 & -0.2 & 5 & 27.5 \\
\hline 37 & Colias hyale & 0 & 0.0 & 68 & 0.9 & -0.9 & 3 & 42.0 \\
\hline 38 & Lycaena virgaureae & 0 & 0.0 & 28 & 0.4 & -0.4 & 4 & 32.0 \\
\hline 39 & Nymphalis antiopa & 0 & 0.0 & 6 & 0.1 & -0.1 & 6 & 72.5 \\
\hline 40 & Polygonia c-album & 0 & 0.0 & 8 & 0.1 & -0.1 & 6 & 48.0 \\
\hline 41 & Polyommatus coridon & 0 & 0.0 & 40 & 0.5 & -0.5 & 4 & 35.0 \\
\hline \multirow[t]{2}{*}{42} & Vanessa cardui & 0 & 0.0 & 77 & 1.0 & -1.0 & 8 & 57.5 \\
\hline & Total & 561 & 100 & 7714 & 100 & - & - & - \\
\hline
\end{tabular}

Fourteen equally good models which explained the proportion of species killed on roads were identified (see Supplementary material). All the best models explained $13 \%$ of variation, on average (see Supplementary material). The proportion was positively dependent on the cover of human settlements in a $1-\mathrm{km}$ radius, the road width, the forest cover in a $1-\mathrm{km}$ radius, the index of mowing frequency and the traffic volume (Table 3 ). The proportion was negatively affected by plant species richness (Table 3 ).

Five equally good models which explained the proportion of individuals killed on roads were identified (see Supplementary material). The best models explained $39 \%$ of variation, on average. The proportion was positively dependent on the proportion of human settlement in a $1-\mathrm{km}$ radius, the forest cover in a $1-\mathrm{km}$ radius and the road width (Table 3 ). The proportion decreased with the abundance of butterflies on the road verges, the grassland cover in a $1-\mathrm{km}$ radius and the plant species richness, after controlling the positive effect of the total sample size on the estimation of the proportion (Table 3 ).

\subsection{Factors affecting the number of species and individuals living at road verges}

The model selection based on Akaike's criterion showed that four models explaining butterfly species richness at road verges were equally good (see Supplementary material). The best models explained, on average, $39 \%$ of variation in butterfly species richness (see Supplementary material). The explanatory variables that were present in all best models were the verge width and the grassland cover in $1-\mathrm{km}$ radius (Table 3 ). The richness of butterfly species was also positively dependent on the cover of human settlements in a $1-\mathrm{km}$ radius and the number of plant species (Table 3 ).

Model selection identified three equally good models describing the abundance of butterflies at road verges (see Supplementary material). The best models explained $56 \%$ of variation, on average (see Supplementary material). The abundance of butterflies on road verges was positively affected by the grassland cover in a 1$\mathrm{km}$ radius, verge width, the forest cover in a $1-\mathrm{km}$ radius and the plant species richness (Table 3 ).

The summarized comparisons of the above effects with the factors affecting roadkills are given in the Supplementary material.

\subsection{Species composition of roadkills and butterflies on road verges}

Four axes in the RDA explained $15 \%$ of variation in the species composition in roadkills, of which $80 \%$ were explained by environmental variables (significance of axes: $F=1.447, P=0.004$ ). However, we found that the species composition of roadkills was also well explained by the species composition of the butterflies living 
Table 3

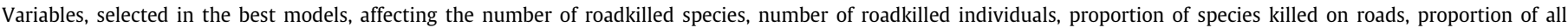

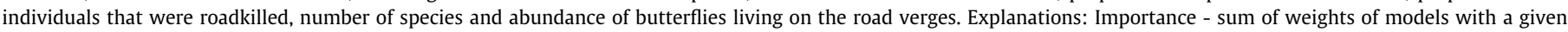

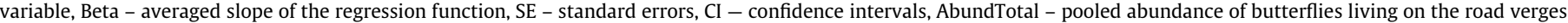
and roadkills. For explanation of other variable codes see Table 1. Variables are sorted according to their importance.

\begin{tabular}{|c|c|c|c|c|c|}
\hline No. & Variable & Importance & Beta \pm SE & Lower 95\% CI & Upper 95\% CI \\
\hline & Number of ro & & & & \\
\hline 1 & Species & 1.000 & $1.859 \pm 0.326$ & 1.220 & 2.498 \\
\hline 2 & Mown & 0.821 & $0.633 \pm 0.226$ & 0.190 & 1.076 \\
\hline 3 & Grass & 0.569 & $0.526 \pm 0.177$ & 0.179 & 0.872 \\
\hline 4 & ForCov & 0.560 & $0.482 \pm 0.161$ & 0.166 & 0.797 \\
\hline \multirow[t]{2}{*}{5} & Traffic & 0.354 & $0.314 \pm 0.100$ & 0.119 & 0.509 \\
\hline & Number of ro & & & & \\
\hline 1 & Abund & 1.000 & $3.717 \pm 0.721$ & 2.304 & 5.130 \\
\hline 2 & Traffic & 0.675 & $1.071 \pm 0.371$ & 0.343 & 1.798 \\
\hline 3 & Grass & 0.603 & $1.156 \pm 0.394$ & 0.384 & 1.927 \\
\hline 4 & Plant & 0.511 & $-0.879 \pm 0.290$ & -1.447 & -0.312 \\
\hline 5 & Mown & 0.509 & $0.807 \pm 0.263$ & 0.291 & 1.323 \\
\hline 6 & RoadW & 0.471 & $0.766 \pm 0.246$ & 0.283 & 1.249 \\
\hline \multirow[t]{2}{*}{7} & VergeW & 0.259 & $-0.409 \pm 0.171$ & -0.744 & -0.073 \\
\hline & Proportion of & oads & & & \\
\hline 1 & Built & 0.722 & $0.060 \pm 0.012$ & 0.018 & 0.102 \\
\hline 2 & RoadW & 0.569 & $0.051 \pm 0.017$ & 0.017 & 0.085 \\
\hline 3 & Plant & 0.436 & $-0.040 \pm 0.013$ & -0.066 & -0.015 \\
\hline 4 & ForCov & 0.435 & $0.042 \pm 0.014$ & 0.015 & 0.068 \\
\hline 5 & Mown & 0.337 & $0.030 \pm 0.010$ & 0.011 & 0.050 \\
\hline \multirow[t]{2}{*}{6} & Traffic & 0.284 & $0.022 \pm 0.009$ & 0.005 & 0.040 \\
\hline & Proportion of & on roads & & & \\
\hline 1 & Abund & 1.000 & $-1.182 \pm 0.236$ & -1.644 & -0.720 \\
\hline 2 & AbundTotal & 1.000 & $1.157 \pm 0.236$ & 0.696 & 1.619 \\
\hline 3 & Built & 0.875 & $0.031 \pm 0.011$ & 0.010 & 0.053 \\
\hline 4 & RoadW & 0.320 & $0.013 \pm 0.004$ & 0.005 & 0.021 \\
\hline 5 & ForCov & 0.306 & $0.012 \pm 0.004$ & 0.004 & 0.020 \\
\hline 6 & Grass & 0.284 & $-0.013 \pm 0.004$ & -0.022 & -0.004 \\
\hline \multirow[t]{2}{*}{7} & Plant & 0.261 & $-0.013 \pm 0.003$ & -0.014 & -0.001 \\
\hline & Number of $s p$ & verges & & & \\
\hline 1 & VergeW & 0.995 & $2.693 \pm 0.730$ & 1.262 & 4.125 \\
\hline 2 & Grass & 0.951 & $2.112 \pm 0.329$ & 0.742 & 3.482 \\
\hline 3 & Built & 0.517 & $1.097 \pm 0.363$ & 0.386 & 1.809 \\
\hline \multirow[t]{2}{*}{4} & Plant & 0.317 & $0.665 \pm 0.223$ & 0.227 & 1.103 \\
\hline & Abundance o & & & & \\
\hline 1 & Grass & 1.000 & $31.536 \pm 7.009$ & 17.799 & 45.272 \\
\hline 2 & VergeW & 0.999 & $28.563 \pm 6.947$ & 14.949 & 42.179 \\
\hline 3 & ForCov & 0.855 & $16.041 \pm 5.683$ & 4.902 & 27.179 \\
\hline 4 & Plant & 0.465 & $9.643 \pm 3.104$ & 3.559 & 15.727 \\
\hline
\end{tabular}

on the road verges alone (Fig. 2). Four axes of the RDA explained $40 \%$ of variation in the species composition of the roadkills, of which the species abundances of the butterflies living on the road verges explained 50\% $(F=1.783, P=0.002)$. We therefore performed a partial RDA with the environmental explanatory variables and species abundance on road verges as covariates. Four axes of the partial RDA explained $44 \%$ of variation in the species composition of the roadkills, of which $81 \%$ were explained by environmental variables after controlling the abundance of butterfly species on the road verges (Fig. 2). However, the ordination axes represented a variation that could not be distinguished from a random one because the permutation test of the axes was non-significant $(F=1.297, P=0.122)$. When we repeated this analysis with a forward selection of environmental variables, none was statistically significant. Finally, we performed a partial RDA with species abundance on the road verges being treated as explanatory variables and the environmental variables included as covariates. In this analysis, four axes of the partial RDA explained $41 \%$ variation in the species composition of the roadkills, of which $47 \%$ were explained by butterfly abundance on the road verges, after controlling the effect of the environmental variables $(F=1.811, P=0.002)$.

Four axes of RDA explained $29 \%$ variation in the species composition on the road verges, of which $86 \%$ were explained by environmental variables $(F=1.621, P=0.002)$. When we performed this analysis with a forwards selection of environmental variables, those that significantly explained a variation in butterfly species composition on road verges were the verge width $(F=4.33$, $P=0.002)$, the grassland cover in a $1-\mathrm{km}$ radius $(F=2.66$, $P=0.002)$ and the index of mowing frequency $(F=1.66$, $P=0.048$ ) (see Fig. 2).

\subsection{Species traits and road mortality}

We found that some species were significantly overrepresented in roadkills, while others were underrepresented $\left(\chi_{41}^{2}=458.917\right.$, $P<0.001$, Table 2) when compared with the sample of butterflies abundance on the road verges. The difference between the percentage share in roadkills and the percentage share on the road verges was mostly explained by the body size index (beta $=-1.020 \pm$ $0.325,95 \%$ CI: -1.695 to -0.345 , importance: 0.945 , Fig. 3) (see Supplementary material). Adding the mobility index to the model did not improve it (see Supplementary material) and the effect was statistically non-significant (beta $=-0.265 \pm 0.303,95 \% \mathrm{Cl}$ : $-0.876-0.348$, importance: 0.166 ). Mobility alone also had no support in comparison with the model that only included the body size index (see Supplementary material). Butterflies abundance had no significant effect (the confidence intervals overlapped with zero); despite this, however, it was found in one of the two best 

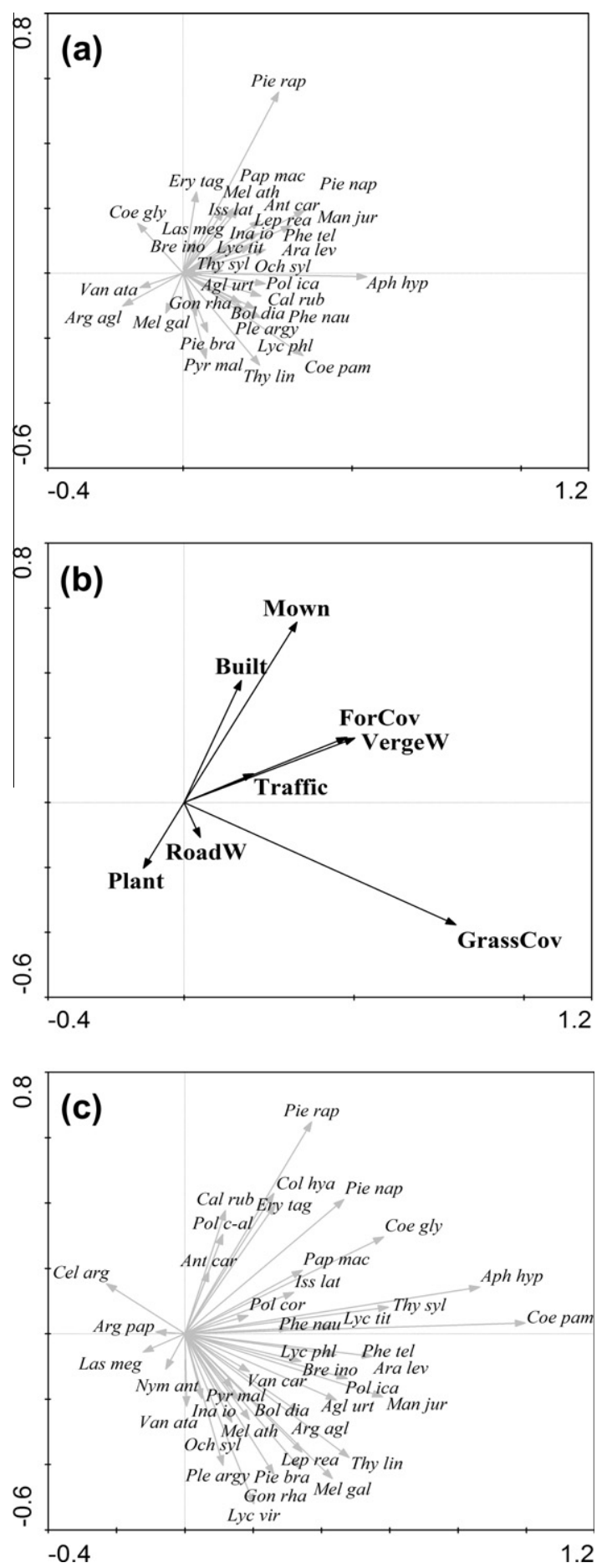

Fig. 2. RDA ordination of butterfly species found killed on the road (a) alive on the road verges (c) and in relation to environmental factors (b). The species are identified by their abbreviated scientific names. Species occurring in less than five transects have been omitted. The environmental variable labels are explained in Table 1.

models (beta $=-0.358 \pm 0.269,95 \% \mathrm{CI}:-0.908-0.191$, importance: 0.377).

\section{Discussion}

The difficulty in understanding the impact of road mortality on the conservation value of road verges stems from the fact that similar environmental factors affect both the number of roadkills and the species richness and abundance of butterflies on road verges.

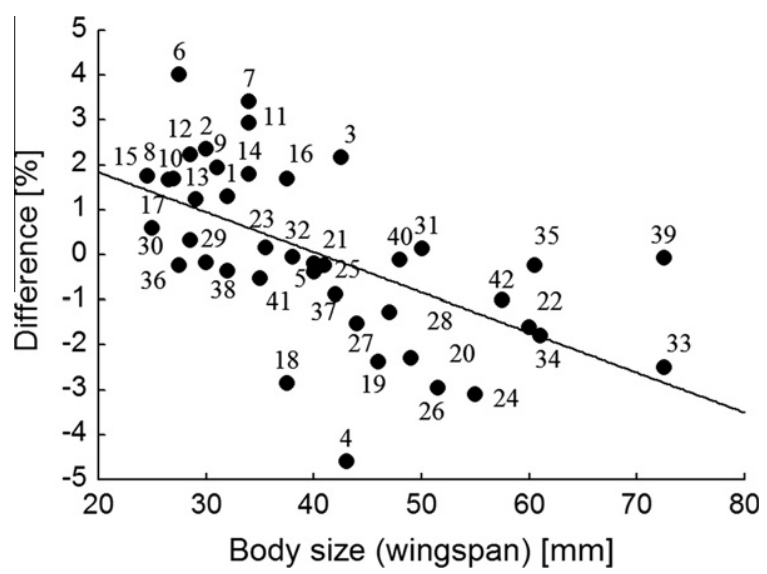

Fig. 3. Effect of body size index (wingspan) on the difference between the percentage share of a species in a group of roadkills and its percentage share in the community of live butterflies on the road verges. The numbers indicating the species are as given in Table 2 .

Our results indicate that road mortality in butterflies is, to some degree, a random process, shaped predominantly by species composition and the abundance of butterflies on road verges, despite the fact that some species, mainly the smaller ones, had a tendency to be overrepresented in roadkills. Traffic volume, road width and verge mowing increase road mortality, while large verge width and plant species richness may significantly reduce the number of roadkills in butterflies on road verges. Landscape composition also has significant effect on the number of roadkills, with various landscape elements affecting road mortality and its impact on butterfly populations on verges differently. We are thus able to provide some clues as to how to manage verges in order to improve their value to butterflies and further decrease the impact of road mortality.

We found that the number of roadkilled species and individuals increased with species richness and abundance on road verges, respectively. This would suggest that the higher the species richness and abundance of butterflies on road verges, the greater the impact of road mortality. However, such is not the case. When we compared the proportions of roadkilled species and individuals, we found that species richness and abundances on road verges did not affect the proportion of roadkilled species or negatively affect the proportion of roadkilled individuals. This means that the larger the butterfly population sizes on road verges, the lower the impact of road mortality on their population sizes will be. Contrary to expectations, this indicates that road verges of the greatest suitability for butterflies may suffer the least from road mortality.

Traffic volume had an important, and obvious, effect on the number of roadkilled species and individuals, and it also positively affected the proportion of the species that were killed by vehicles. However, this factor had no significant effect on either species richness or the abundance of butterflies on road verges. This indicates that the high conservation value of road verges for butterflies may by achieved on any road, regardless of the traffic volume. Some studies suggest the regulation of traffic volume or speed in order to minimize the number of insect roadkills (Rao and Girish, 2007). In our opinion, the regulation of traffic volume is impractical in the case of butterflies. Our study shows the number of roadkills increasing linearly with traffic, in contrast the study conducted by Mckenna et al. (2001), who found that road mortality was highest in roads with an intermediate traffic volume. However, without a count being made of the butterflies on the verges or in the vicinity of the road, it is difficult to disentangle their results in terms of whether they indicated that traffic volume had a real impact of traffic on the butterfly population size on road verges or whether 
this was mediated by a possibly different management regime for the road verges and thus by butterfly habitat disturbance on roads with different levels of traffic.

Road width was a significant factor increasing the number of roadkills and proportion of roadkilled species and individuals. This factor operated independently of the traffic volume, with a weak correlation between the two $(r=0.024, P=0.856)$. When crossing a road, a great many butterflies usually fly at a low altitude, close to the asphalt, and in a zigzag or looping pattern (authors' unpublished data). Thus, the wider the road, the longer the time spent there by butterflies and, in consequence, the greater the number of encounters with vehicles that can cause death. In general, it is difficult to imagine that roads could be narrower than they currently are. There is an increasing tendency to widen up the roads in our study area owing to the increasing volume of traffic (Kotlarek, 2007). In wide roads of this kind, conservation action should thus focus more on managing verges to create a habitat which will not provoke butterflies into crossing the road.

The most important factors that, if appropriately altered, may minimize the negative effects of traffic volume and road width were plant species richness, verge width and mowing frequency. Plant species richness seems to be a particularly important factor. Although its statistical importance was not as large as that of butterfly species richness and abundance, it affected roadkills and live butterflies in a different way, despite the strong positive correlation between the last two variables. Thus, the positive impact of plant species richness on butterflies on road verges was probably much stronger than is indicated by our statistical tests. Plant species richness decreased the number of roadkills, the proportion of roadkilled species and the proportion of roadkilled individuals. Simultaneously, it had a significant positive effect on the species richness and abundance of butterflies on the road verges. Thus, the management of road verges should aim to increase plant species and this can be achieved by (1) giving time for verge communities to develop without major disturbances, so that local plant species and strains from surrounding grasslands can spread naturally to road verges and (2) by sowing flowering and host plants on road verges. Sowing plants is a commonly applied measure (Nordbakken et al., 2010), because many butterfly species rely on specific plants during some of their life stages (Ries et al., 2001; Kitahara et al., 2008). However, we believe these plants should be derived from the landscape surrounding a given verge because this may have positive feedback on butterflies from this landscape (alternatively, plant species on verges might be matched to that in a landscape but with seeds coming from non-local sources). For example, if plants sown on verges were derived from the nearby grasslands it would make the road verge a suitable habitat for butterflies immigrating from these grasslands. Opposite is also true: butterflies reproducing on road verges and then emigrating to other areas would have a chance to settle in the nearby grasslands if plants on road verges and these grasslands were similar. We also think that sowing flowering and butterfly host plants should be recommended as a standard technique during the creation or maintenance of roads, in order to mitigate the environmental costs that they bring with them.

Verge width negatively affected the number of roadkills and had no effect on the proportion of roadkilled species and individuals, but positively affected both species number and abundance of alive butterflies. Thus, extending the width of verges could prove to be a positive action, mitigating the negative effects of road mortality. In a $400 \mathrm{~m}$ long verge, increasing the width by one meter may add around two species and over 25 individuals. This is mirrored in the ordination analysis, which shows that verge width significantly influenced species composition. The verges of many of the roads in our study area could have been much wider that they actually are. Road verges often have a specific microclimate and microhabitats where highly insolated areas abut humid ditches and such strong gradients may be favored by some butterflies (Munguira and Thomas, 1992). Our results are in agreement with other studies (Munguira and Thomas, 1992; Ries et al., 2001; Saarinen et al., 2005) showing that wide verges are inhabited by larger number of butterflies than narrow ones.

Mowing frequency appeared to be a factor which substantially increased both the number of roadkilled species and individuals, as well as the proportion of species killed by vehicles. Mowing is a disturbance that may increase dispersal (Weber et al., 2008) and thus cause frequent road crossings, exposing butterflies to collisions with vehicles. However, surprisingly, and in contrast to earlier studies (Valtonen et al., 2006), mowing had no visible impact on species richness and abundance. This discrepancy may be explained by the fact that the majority of the verges in our study area were partially mown, which seems to be favorable management from the butterfly point of view (Valtonen et al., 2006; Noordijk et al., 2009). However, our ordination analysis showed that mowing is one of the most important factors influencing species composition on road verges. Even if the verges were mown entirely, the work was usually carried out on one side of the road first, with the other side being cut a few days later. It is possible that this allowed the butterflies to fly from the one side of the road to the other both in order to escape from the mowing and, later, to recolonize their previously disturbed habitat. Thus, mowing verges on both sides of the road at different time, even if unintentional, seems to be favorable to the conservation of butterflies on road verges. Mowing should be done after the flight period, preferably no earlier than in mid September (cf. Grill et al., 2008) to prevent woody species encroachment except on the inside of bends of verges where more frequent mowing would enhance road safety.

Landscape composition may greatly influence the number of roadkills in different animals (Hels and Buchwald, 2001; Erritzoe et al., 2003; Orlowski, 2008). Among the factors analyzed in our study, the grassland cover in the vicinity of roads seems to be of particular significance. Although it increased the number of roadkilled species and individuals, it also substantially increased species richness and the abundance of butterflies on road verges. Moreover, it decreased the proportion of individuals that were roadkilled. Grasslands probably fulfill the role of a species pool (Öckinger and Smith, 2007) that enables butterflies to colonize verges or survive the periods when the verges are mown in their entirety. Thus grassland in the vicinity of roads increases the conservation value of the verges.

Contrary to this, forest cover increased butterfly road mortality and species richness and abundance on road verges. However, it also increased the proportion of roadkilled species and individuals. Therefore, the forests in the vicinity of roads may diminish the conservation value of the verges for butterflies. This finding contrasts with the conclusions drawn in a study by Saarinen et al. (2005). In fact, a few butterflies inhabit forests (for example, Argynnis aglaja, A. paphia, Melitea athalia) and the proximity of forests may explain their occurrence on verges. The edges of forest may provide warmer microhabitats than surrounding landscape and may be used by butterflies as dispersal conduits (Öckinger et al., 2012). Thus forests in the vicinity of roads may direct migrating individuals to verges and increase their influx onto roads and, therefore, into collision with vehicles. It is also possible that the proximity of forests alters microclimate of road verges, which may cause some butterflies to leave the verge or settle on the warmer asphalt ( $\mathrm{Da}$ vies-Colley et al., 2000; Meyer and Sisk, 2001).

The effect of human settlements is even more difficult to understand than that of forest cover. Although the settlements did not increase the number of roadkills, they did increase the proportion of species and individuals killed by vehicles. Munguira and Thomas (1992) found that the number of roadkills was larger in the 
proximity of buildings. Human settlement also increased the number of species on verges. In farmland areas, human settlements often have small gardens with numerous flowers that can provide a supplementary resource for butterflies (Rosin et al., 2011) and this may explain the positive effects of human settlements on species richness found in our study. However, the mechanism leading to the increased proportion of roadkills is difficult to extrapolate.

We found that small species were overrepresented in our sample of roadkills, but that butterfly mobility had no effect on road mortality. Our other study (Skórka et al., unpublished) showed that dead small species are usually slightly less detectable on roads than larger ones. Over $90 \%$ of all roadkills are detected in large species and at least $70 \%$ in small ones. Thus, in reality, small species are even more susceptible to collision with vehicles than was found in our study. Small insects fly over the asphalt at a low altitude while crossing the road (Soluk et al., 2011) and thus small butterflies may be especially susceptible to deadly collision with vehicles. Larger species, on the other hand, often cross roads at a higher altitude, mainly above the height of passing cars. From the conservation point of view, this may be a serious problem, because linear habitats such as road verges seem to be especially valuable for smaller species requiring a less spacious area in which to live than larger ones do (Soderstrom and Hedblom, 2007). Thus, as stated previously, specific road verge management aimed at reducing the road crossing rate is necessary. More behavioral observations are also required in order to understand why smaller species suffer more from road mortality than larger ones.

\subsection{Conclusions}

Our composite study is the first to explore the interrelations between road mortality, the suitability of road verges as habitats for butterflies and species-specific traits in detail. Although road mortality does not affect that large a part of butterfly populations, the opportunity to take further measures to minimize collisions with vehicles still exists. In our opinion, the notion of altering traffic volume or road size is extremely difficult to put into practice. What we therefore propose is a focus on the management of road verges and the surrounding landscape. First, actions increasing the butterfly population size on road verges by sowing flowering and host plants from the surrounding landscape are encouraged. Road verges should be as wide as possible and be mown either rarely or partial. Patches of grasslands in the vicinity of roads are a requisite element in a landscape. Special attention should be paid to the management of verges for smaller butterflies. Furthermore, the two sides of the road should be mown at different times. Finally, further behavioral studies may shed some light on the mechanisms leading to collisions of insects with vehicles.

\section{Acknowledgements}

We thank Robin Pakeman and two anonymous referees for their helpful comments on the manuscript. This study was financed by the Polish Ministry of Science and Higher Education under project number N N304 030139.

\section{Appendix A. Supplementary material}

Supplementary data associated with this article can be found, in the online version, at http://dx.doi.org/10.1016/j.biocon.2012.12. 028.

\section{References}

Anonymous, 2007. Planning of the Road Develpement in Malopolska Voivodoship 2007-2013. <http://www.wrotamalopolski.pl/NR/rdonlyres/1EA65A73-82E244FD-BCE5-99D45DC194DD/339120/773zal.pdf>.

Berg, Å., Ahrné, K., Öckinger, E., Svensson, R., Söderström, B., 2011. Butterfly distribution and abundance is affected by variation in the Swedish forestfarmland landscape. Biol. Conserv. 144, 2819-2831.

Bhattacharya, M., Primack, R.B., Gerwein, J., 2003. Are roads and railroads barriers to bumblebee movement in a temperate suburban conservation area? Biol. Conserv. 109, 37-45.

Biesmeijer, J.C., Roberts, S.P.M., Reemer, M., Ohlemüller, R., Edwards, M., Peeters, T., Schaffers, A.P., Potts, S.G., Kleukers, R., Thomas, C.D., Settele, J., Kunin, W.E. 2006. Parallel declines in pollinators and insect-pollinated plants in Britain and the Netherlands. Science 313, 351-354.

ter Braak, C.J.F., Šmilauer, P., 2002. CANOCO Reference Manual and CanoDraw for Windows User's Guide: Software for Canonical Community Ordination (Version 4.5). Ithaca NY, USA: Microcomputer Power. <www.canoco.com>.

Burnham, K.P., Anderson, D.R., 2002. Model Selection and Multimodel Inference Springer, New York

Davies-Colley, R.J., Payne, G.W., van Elswijk, M., 2000. Microclimate gradients across a forest edge. New Zealand J. Ecol. 24, 111-121.

Dover, J.W., Rescia, A., Fungariño, S., Fairburn, J., Carey, P., Lunt, P., Dennis, R.L.H., Dover, C.J., 2010. Can hay harvesting detrimentally affect adult butterfly abundance? J. Insect Conserv. 14, 413-418.

Erritzoe, J., Mazgajski, T.D., Rejt, Ł., 2003. Bird casualties on European roads - a review. Acta Ornithol. 38, 77-93.

Fahrig, L., 2003. Effects of habitat fragmentation on biodiversity. Annu. Rev. Ecol Evol. Syst. 34, 487-515.

Fahrig, L., Rytwinski, T., 2009. Effects of roads on animal abundance: an empirical review and synthesis. Ecol. Soc. 14 (1), 21, <http://www.ecologyandsociety.org/ vol14/iss1/art21/>.

Forman, R.T.T., Alexander, L.E., 1998. Roads and their major ecological effects. Annu. Rev. Ecol. Syst. 29, 207-231.

Forman, R.T.T., Sperling, D., Bissonette, J.A., Clevenger, A.P., Cutshall, C.D., Dale, V.H. Fahrig, L., France, R., Goldman, C.R., Heanue, K., Jones, J.A., Swanson, F.J. Turrentine, T., Winter, T.C., 2003. Road Ecology: Science and Solutions. Island Press, Washington, DC, USA.

Grill, A., Cleary, D.F.R., Stettmer, C., Bräu, M., Settele, J., 2008. A mowing experiment to evaluate the influence of management on the activity of host ants of Maculinea butterflies. J. Insect Conserv. 12, 617-627.

Heliölä, J., Kuussaari, M., 2005. How many counts are needed? Effect of sampling effort on observed species number of butterflies and moths in transect counts. In: Kuehn, E., Thomas, J., Feldmann, R., Settele, J. (Eds.), Studies on the Ecology and Conservation of Butterflies in Europe: General Concepts and Case Studies. Proceedings of the Conference held in UFZ Leipzig, 5-9th of December, 2005, vol. 1. PENSOFT Publishers, Sofia, pp. 83-84.

Hels, T., Buchwald, E., 2001. The effect of road kills on amphibian populations. Biol. Conserv. 99, 331-340.

Jackson, N.D., Fahrig, L., 2011. Relative effects of road mortality and decreased connectivity on population genetic diversity. Biol. Conserv. 144, 3143-3148.

Kingsolver, J.G., Srygley, R.B., 2000. Experimental analyses of body size, flight and survival in pierid butterflies. Evol. Ecol. Res. 2, 593-612.

Kitahara, M., Yumoto, M., Kobayashi, T., 2008. Relationship of butterfly diversity with nectar plant species richness in and around the Aokigahara primary woodland of Mount Fuji. Central Jpn. Biodiver. Conserv. 17, 2713-2734.

Kotlarek, Z., 2007. National Plan for the Road-Network Development 2007-2013. <http://www.gddkia.gov.pl>.

Lorenc, H., 2005. Atlas of the Climate of Poland. IMiGW, Warszawa.

Mckenna, D.D., Mckenna, K.M., Malcom, S.B., Berenbaum, M.R., 2001. Mortality of Lepidoptera along roadways in central Illinois. J. Lepidopt. Soc. 55 63-68.

Meyer, C.L., Sisk, T.D., 2001. Butterfly response to microclimatic conditions following ponderosa pine restoration. Restor. Ecol. 9, 453-461.

Munguira, M.L., Thomas, J.A., 1992. Use of road verges by butterfly and burnet populations, and the effect of roads on adult dispersal and mortality. J. Appl. Ecol. 29, 316-329.

Neumann, W., Ericsson, G., Dettki, H., Bunnefeld, N., Keuler, N.S., Helmers, D.P. Radeloff, V.C., 2012. Difference in spatiotemporal patterns of wildlife roadcrossings and wildlife-vehicle collisions. Biol. Conserv. 145, 70-78.

Noordijk, J., Delille, K., Schaffers, A.P., Sýkora, K.V., 2009. Optimizing grassland management for flower-visiting insects in roadside verges. Biol. Conserv. 142 2097-2103.

Nordbakken, J.F., Rydgren, K., Auestad, I., Austad, I., 2010. Successful creation of species-rich grassland on road verges depend on various methods for seed transfer. Urban Forest. Urban Green. 9, 43-47.

Nowicki, P., Vrabec, V., 2011. Evidence for positive density-dependent emigration in butterfly metapopulations. Oecologia 167, 657-665.

Öckinger, E., Smith, H.G., 2007. Semi-natural grasslands as population sources for pollinating insects in agricultural landscapes. J. Appl. Ecol. 44, 50-59.

Öckinger, E., Bergman, K.-O., Franzén, M., Kadlec, T., Krauss, J., Kuussaari, M., Pöyry, J., Smith, H., Steffan-Dewenter, I., Bommarco, R., 2012. The landscape matrix modifies the effect of habitat fragmentation in grassland butterflies. Land. Ecol. 27, 121-131. 
Orlowski, G., 2008. Roadside hedgerows and trees as factors increasing road mortality of birds: implications for management of roadside vegetation in rural landscapes. Land. Urban Plan. 86, 153-161.

Quinn, G.P., Keough, M.J., 2002. Experimental Design and Data Analysis for Biologists. Cambridge University Press, Cambridge.

Rangel, T.F.L.V.B., Diniz-Filho, A.F., Bini, L.M., 2010. SAM: a comprehensive application for spatial analysis in macroecology. Ecography 33, 46-50.

Rao, R.S.P., Girish, M.K.S., 2007. Road kills: assessing insect causalities using flagship taxon. Curr. Sci. 92, 830-837.

Ries, L., Debinski, D.M., Wieland, M.L., 2001. Conservation value of roadside prairie restoration to butterfly communities. Conserv. Biol. 15, 401-411.

Rosin, Z.M., Skórka, P., Lenda, M., Moron, D., Sparks, T.H., Tryjanowski, P., 2011. Increasing patch area, proximity of human settlement and larval food plants positively affect the occurrence and local population size of the habitat specialist butterfly Polyommatus coridon (Lepidoptera: Lycaenidae) in fragmented calcareous grassland. Eur. J. Entomol. 108, 99-106.

Saarinen, K., Valtonen, A., Jantunen, J., Saarnio, S., 2005. Butterflies and diurnal moths along road verges: does road type affect diversity and abundance? Biol. Conserv. 123, 403-412.

Selva, N., Kreft, S., Kati, V., Schluck, M., Jonsson, B.-G., Mihok, B., Okarma, H., Ibisch, P.L., 2011. Roadless and low-traffic areas as conservation targets in Europe. Environ. Manage. 48, 865-877.

Settele, J., Feldmann, R., Reinhardt, R., 2000. Die Tagfalter Deutschlands Ulmer, Stuttgart, Germany.

Shepard, D.B., Kuhns, A., Dreslik, M.J., Philips, C.A., 2008. Roads as barriers to animal movement in fragmented landscapes. Anim. Conserv. 11, 288-296.

Sielezniew, M., Dziekanska, I., 2010. Butterflies. Multico, Warszawa.

Silva, C.C., Lourenço, R., Godinho, S., Gomes, E., Sabino-Marques, H., Medinas, D. Neves, V., Silva, C., Rabaça, J.E., Mira, A., 2012. Major roads have a negative impact on the Tawny Owl Strix aluco and the Little Owl Athene noctua populations. Acta Ornithol. 47, 47-54.

Skórka, P., Settele, J., Woyciechowski, M., 2007. Effects of management cessation on grassland butterflies in southern Poland. Agric. Ecosyst. Environ. 121, 319-324.

Smith-Patten, B.D., Patten, M.A., 2008. Diversity, seasonality, and context of mammalian roadkils in the southern Great Plains. Environ. Manage. 41, 844852.
Soderstrom, B., Hedblom, M., 2007. Comparing movement of four butterfly species in experimental grassland strips. J. Insect Conserv. 11, 333-342.

Soluk, D.A., Zercher, D.S., Worthington, A.M., 2011. Influence of roadways on patterns of mortality and flight behavior of adult dragonflies near wetland areas. Biol. Conserv. 144, 1638-1643.

Thomas, J.A., Telfer, M.G., Roy, D.B., Preston, C.D., Greenwood, J.J.D., Asher, J., Fox, R., Clarke, R.T., Lawton, J.H., 2004. Comparative losses of British butterflies, birds, and plants and the global extinction crisis. Science 303, 1879-1881.

Trombulak, S.C., Frissell, C.A., 2000. Review of ecological effects of roads on terrestrial and aquatic communities. Conserv. Biol. 14, 18-30.

Valtonen, A., Saarinen, K., Jantunen, J., 2006. Effect of different mowing regimes on butterflies and diurnal moths on road verges. Anim. Biodiver. Conserv. 29, 133148.

Valtonen, A., Saarinen, M., Jantunen, J., 2007. Intersection reservations as habitats for meadow butterflies and diurnal moths: guidelines for planning and management. Land. Urban Plan. 79, 201-209.

Vergnes, A., Le Viol, I., Clergeau, P., 2012. Green corridors in urban landscapes affect the arthropod communities of domestic gardens. Biol. Conserv. 145, 171-178.

Vessby, K. Söderström, B. Glimskär, A. Svensson, B., 2002. Species richness correlations of six different taxa in swedish seminatural grasslands. Conserv. Biol. 16, 430-439.

Warren, M.S., Hill, J.K., Thomas, J.A., Asher, J., Fox, R., Huntley, B., Roy, D.B., Telfer M.G., Jeffcoate, S., Harding, P., Jeffcoate, G., Willis, S.G., Greatorex-Davies, J.N., Moss, D., Thomas, C.D., 2001. Rapid responses of British butterflies to opposing forces of climate and habitat change. Nature 414, 65-69.

Weber, P.G., Preston, S., Dlugos, M.J., Nelson, A.P., 2008. The effects of field mowing on adult butterfly assemblages in central New York state. Nat. Areas J. 28, 130143.

Wickman, P.-O., 1992. Sexual selection and butterfly design - a comparative study. Evolution 46, 1525-1536.

Wiszniewsk, W., 1973. Atlas of the Climate of Poland. IMiGW, Warszawa.

Wynhoff, I., van Gestel, R., van Swaay, C., van Langevelde, F., 2011. Not only the butterflies: managing ants on road verges to benefit Phengaris (Maculinea) butterflies. J. Insect Conserv. 15, 189-206. 